\title{
Uji Aktivitas Antibiofilm Minuman Sinbiotik Terhadap Staphylococcus aureus ATCC 2593
}

\author{
Afivudien Muhammad', Irena Agustiningtyas ${ }^{1}$ \\ 1Departemen Mikrobiologi FK UII, Yogyakarta
}

Submisi: 15 April 2021; Penerimaan: 10 Juli 2021

\begin{abstract}
ABSTRAK
Staphylococcus aureus merupakan salah satu bakteri yang bisa menyebabkan beragam penyakit dan punya kemampuan membentuk biofilm. Sehingga dapat melindungi diri dari antibiotik. Sinbiotik adalah suplemen makanan berbentuk minuman probiotik yang dapat menghambat pertumbuhan bakteri berpotensi patogen, salah satunya Staphylococcus aureus. Tujuan penelitian ini adalah untuk melakukan uji antibiofilm Sinbiotik terhadap Staphylococcus aureus. Penelitian ini merupakan penelitian eksperimental laboratorik dengan menggunakan sampel minuman sinbiotik G12, Biotoksi, dan Yakult. Sinbiotik diujikan pada biofilm Staphylococcus aureus yang sudah mendapatkan perlakuan yaitu dengan menumbuhkan bakteri daslam media Trypticase Soy Broth selama 24 jam pada suhu $37^{\circ} \mathrm{C}$. Dalam penelitian ini analisa data yang digunakan adalan analilis univariat yaitu dengan melihat hasil rata-rata. Penghambatan biofilm yang terjadi diukur menggunakan penghitungan MBIC (Minimum Biofilm Inhibitory Concentration) dan antibiofilm menggunakan spektrofotometer untuk mendapatkan nilai OD. Sinbiotik G12 dan Biotoksi menunjukkan kemampuan antibiofilm terhadap Staphylococcus aureus masing-masing sebesar $70.17 \%$ dan $68.74 \%$. Sedangkan hasil pada yakult sebesar $1101 \%$ sehingga tidak mempunyai kemampuan antibiofilm.Dari hasil tersebut dapat simpulkan bahwa minuman sinbiotik G12 dan Biotoksi mempunyai kemampuan antibiofilm terhadap bakteri Staphylococcus aureus.
\end{abstract}

Kata kunci: antibiofilm; Staphylococcus aureus; sinbiotik; MBIC

\section{LATAR BELAKANG}

Probiotik adalah mikrobia hidup yang bermanfaat bagi hewan atau manusia yang mengkonsumsi dengan meningkatkan keseimbangan mikroflora saluran pencernaan bagian bawah (Fuller \& Fuller, 1992). Probiotik akan efektif jika (a) Menimbulkan efek yang bermanfaat bagi tubuh, (b) Bukan patogen/tidak toksik, (c) Mengandung sejumlah besar sel hidup $\left(10^{8}-10^{12}\right)$ CFU $/ g-1$, (d) Bertahan hidup dalam sistem pencernaan dan tahan terhadap enzim pencernaan tubuh, (e) Tetap hidup saat disimpan dan dikonsumsi, (f) Mempunyai sifat sensoris yang baik, (g) Diisolasi dari spesies yang sama seperti lingkungan tubuh (Winarti, 2018). Menurut FAO/WHO (2002), jumlah yang diperlukan untuk mempertahankan manfaat dari probiotik pada produk pangan adalah minimum mengandung probiotik sebesar $10^{6}-10^{8} \mathrm{CFU} / \mathrm{ml}-1$.

Konsumsi probiotik berguna bagi kesehatan antara lain: menurunkan gejala melabsorpsi laktosa, meningkatkan ketahanan alami terhadap infeksi saluran pencernaan, menekan pertumbuhan sel kanker, menurunkan kolesterol dalam darah, meperbaiki sistem pencernaan dan menstimulasi imunitas saluran pencernaan (Winarti, 2018). Bakteri probiotik harus bertahan hidup dalam saluran pencernaan setelah dikonsumsi. Bakteri ini tahan terhadap lisozim, enzim di air liur, pemecah dinding sel bakteri, dan asam empedu 
untuk sampai di usus dalam keadaan hidup. Bakteri tersebut mampu menempel pada sel ephitelium dan menjaga keharmonisan komposisi bakteri saluran pencernaan. Selanjutnya ia membantu mengatasi intoleransi terhadap laktosa, mencegah diare, sembelit, kanker, hipertensi, 10 menurunkan kolesterol, menormalkan bakteri saluran pencernaan setelah pengobatan antibiotik, serta meningkatkan sistem kekebalan tubuh (Antarini, 2011).

Sinbiotik adalah suplemen makanan berbentuk minuman probiotik. Sinbiotik mengandung bakteri baik Lactobacillus casei shirota strain, yang biasanya juga hidup secara alami dalam usus manusia.Terdapat lebih dari 6,5 miliar Lactobacillus casei dalam setiap botol Sinbiotik. Dengan demikian, Sinbiotik bisa membantu meningkatkan jumlah bakteri baik dalam saluran pencernaan sehingga menghambat perkembangan bakteri jahat penyebab infeksi. Lactobacillus casei digunakan untuk membantu mencegah dan mengobati gangguan pencernaan, seperti: diare, sembelit, sindrom iritasi usus, peradangan usus dan infeksi bakteri.(hellosehat.com)

\section{METODE PENELITIAN}

\section{Tempat dan waktu penelitian}

Penelitian ini dilaksanakan di laboratorium Mikrobiologi, Departemen Mikrobiologi Fakultas Kedokteran Universitas Islam Indonesia. Penelitian ini dilaksabakan mulai bulan Desember 2020 sampai bulan Maret 2021.

\section{Bahan Penelitian}

Bahan yang digunakan penelitian ini adalah minuman Sinbiotik yang dibeli di pasaran yaitu G12, Biotoksi, dan Yakult. Bahan lain yang digunakan dalam penelitian ini adalah bakteri Staphylococcus aureu ATCC 2593,
Trypthon Soya Broth merk oxoid, Trypthon Soya Agar merk oxoid, Standar Mac Farland, $\mathrm{NaCl}$ dan aquades.

\section{Alat Penelitian}

Alat yang digunakan dalam penelitian ini antara lain cawan petri, batang pengaduk kaca, gelas ukur, labu erlenmeyer, termometer, rak tabung, tabung reaksi, mikropipet, ose streril, lampu bunsen, oven merk memert, inkubator merk memert, autoclave merk Hirayama, mikroplate merk eppendrof, Elisa Reader

\section{Prosedur penelitian}

Suspensi bakteri yang sudah distandarisasi kekeruhannya disetarakan dengan standar McFarland. Kemudian diambil sebanyak $100 \mu \mathrm{l}$ dan dicampur dengan konsentrasi minuman Sinbiotik; G12, Biotoksi, dan Yakult dalam mikroplate. Diinkubasi selam $2 \times 24$ pada suhu $37^{\circ} \mathrm{C}$. Larutan dibuang, dicuci dengan PBS sebanyak 200 mikro sampai $3 x$ atau lebih. Larutan dibuang kemudian ditambahkan kristal violet $0.1 \%$ sebanyak 100 mikro, dibuang. Dicuci dengan aquades sampai bersih, ditambahkan asam asetat $33 \%$ sebanyak 100 mikro kemudian dibaca di elisa reader dengan panjang gelombang 620 $\mathrm{nm}$.

Hasil pembacaan tersebut kemudian dimasukkan kedalam rumus untuk mengetahui berapa besar kemampuan penghambatan ekstrak terhadap biofilm uji. Rumus penghambatan biofilm sebagai berikut:

$$
\begin{aligned}
& \text { Inhibitory } \%=\left(\frac{O D c-O D t}{O O c}\right) \times 100 \\
& \text { Keterangan: } \\
& \text { ODc } \quad=\text { kontrol negative; } \\
& \text { ODt } \quad=\text { perlakuan. }
\end{aligned}
$$

\section{Analisa data}

Data hasil yang diperoleh adalah absorbansi( OD). Dihitung kadar hambat 
minimal masing-masing sinbiotik dengan menggunakan rumus:

$$
\% M B I C=\left(\frac{O D K N-O D U j i}{O D} K N\right) \times 100 \%
$$

Keterangan:

$\mathrm{MBIC}=$ Minimum biofilm inhibitory concentration;

ODKN=Optical Density Kontrol

Tabel 1, Tabel 2, dan Tabel 3. negative

\section{HASIL DAN PEMBAHASAN}

Hasil yang didapatkan dari uji aktivitas antibiofilm dari masing-masing sinbiotik yaitu G12, Biotoksi, dan Yakult ditunjukkan pada

Tabel 1. Hasil uji Sinbiotik G12 terhadap antibiofilm Staphylococcus aureus

\begin{tabular}{ccccccc}
\hline \multirow{2}{*}{ Ulangan } & \multicolumn{5}{c}{ Perlakuan G12 } \\
\cline { 2 - 7 } & Antibiofilm & G12 + BHI & G12 & BHI & Kontrol Bakteri & Kontrol Antibiotik \\
\hline 1 & 0,0852 & 0,0879 & 0,068 & 0,0705 & 0,2662 & 0,146 \\
2 & 0,0662 & 0,0777 & 0,0744 & 0,0601 & 0,2086 & 0,1381 \\
3 & 0,0663 & 0,0764 & 0,0733 & 0,0658 & 0,2158 & 0,1683 \\
4 & 0,0759 & 0,0952 & 0,0761 & 0,0678 & 0,2651 & 0,1116 \\
5 & 0,0694 & 0,101 & 0,0809 & 0,0768 & 0,2617 & 0,1286 \\
Rata2 & 0,0726 & & & & 0,24348 & \\
\hline
\end{tabular}

Standar deviasi 0.008071

Tabel 2. Hasil uji Sinbiotik Biotoksi terhadap antibiofilm Staphylococcus aureus

\begin{tabular}{ccccccc}
\hline \multirow{2}{*}{ Ulangan } & \multicolumn{5}{c}{ Perlakuan Biotoksi } \\
\cline { 2 - 6 } & Antibiofilm & Biotoksi + BHI & Biotoksi & BHI & Kontrol Bakteri & Kontrol Antibiotik \\
\hline 1 & 0,0905 & 0,1095 & 0,0829 & 0,0705 & 0,2662 & 0,146 \\
2 & 0,0662 & 0,0969 & 0,0906 & 0,0601 & 0,2086 & 0,1381 \\
3 & 0,0737 & 0,1132 & 0,0866 & 0,0658 & 0,2158 & 0,1683 \\
4 & 0,0855 & 0,1008 & 0,089 & 0,0678 & 0,2651 & 0,1116 \\
5 & 0,0647 & 0,1116 & 0,0961 & 0,0768 & 0,2617 & 0,1286 \\
Rata2 & 0,07612 & & & & 0,24348 & \\
\hline
\end{tabular}

Standar deviasi 0.011505

Tabel 3. Hasil uji Sinbiotik Yakult terhadap antibiofilm Staphylococcus aureus

\begin{tabular}{ccccccc}
\hline \multirow{2}{*}{ Pengulangan } & \multicolumn{5}{c}{ Perlakuan Yakult } \\
\cline { 2 - 7 } & Antibiofilm & $\begin{array}{c}\text { Yakult } \\
+ \text { BHI }\end{array}$ & Yakult & BHI & $\begin{array}{c}\text { Kontrol } \\
\text { Bakteri }\end{array}$ & $\begin{array}{c}\text { Kontrol } \\
\text { Antibiotik }\end{array}$ \\
\hline 1 & 0,2768 & 0,2467 & 0,2628 & 0,0705 & 0,2158 & 0,146 \\
2 & 0,2525 & 0,231 & 0,2767 & 0,0601 & 0,2086 & 0,1381 \\
3 & 0,2355 & 0,2131 & 0,2949 & 0,0658 & 0,2662 & 0,1683 \\
4 & 0,2396 & 0,2757 & 0,2923 & 0,0678 & 0,2651 & 0,1116 \\
5 & 0,2297 & 0,2792 & 0,4268 & 0,0768 & 0,2617 & 0,1286 \\
\hline Rata2 & 0,23493333 & & & & 0,264333333 &
\end{tabular}

Standar deviasi 0.018738

Daya penghambatan merupakan konsentrasi ekstrak paling rendah yang 
dapat menghambat $50 \%$ pertumbuhan biofilm ( Pratiwi et al, 2015; Chaerunisa, 2015).

Berdasarkan perhitungan MBIC maka didapatkan hasil sebagai berikut:

$$
\begin{aligned}
& \text { G12: }=\left(\frac{0.24348-0.0726}{0.24348}\right) \times 100 \% \\
& =70.17
\end{aligned} \begin{gathered}
0.24348 \\
\text { Biotoksi }=\left(\frac{0.24348-0.07612}{6.74} \times 100 \%\right. \\
\text { Yakult }=\left(\left(0.2643-\frac{0.2349}{0.2643}\right) \times 100 \%\right. \\
=11.01
\end{gathered}
$$

Uji aktivitas antibiofilm ini bertujuan untuk mengetahui kemampuan dari 3 jenis minuman sinbiotik dalam menghambat pertumbuhan bakteri yang diujikan. Minuman sinbiotik biotoksi ini

Tabel 1, Tabel 2, dan Tabel 3 minuman sinbiotik G12 dan dan Biotoksi menunjukkan kemampuan sebagai antibiofilm terhadap Staphylococcus aureus masing-masing sebesar $70.17 \%$ dan $68.74 \%$. Dikarenakan dalam minuman sinbiotik G12 dan Biotoksi didalamnya terkandung bermacam jenis bakteri probiotik atau yang sering disebut dengan probiotik komunitas. Sedangkan dalam minuman sinbiotik yakult hanya terdapat satu macam bakteri probiotik yaitu bakteri Lactobacillus casei shirota strain.

Manfaat Sinbiotik secara lebih spesifik terletak pada kemampuan bakteri bermanfaat untuk hidup sampai usus 11 manusia untuk melawan bakteri merugikan, meningkatkan keseimbangan mikroflora saluran pencernaan bagian bawah (Fuller, 1992). Sinbiotik mengandung bakteri baik Lactobacillus casei shirota strain, membantu meningkatkan jumlah bakteri baik dalam saluran pencernaan sehingga menghambat perkembangan bakteri jahat penyebab infeksi.

\section{KESIMPULAN}

terdiri dari berbagai jenis bakeri probiotik kompleks yang membentuk suatu komunitas bakteri sehingga bakteri tersebut dapat bekerja dengan komprehensif tanpa adanya suatu dominansi suatu jenis bakteri saja. Bakteri - bakteri yang terkandung dalam minuman sinbiotik biotoksi ini antara lain adalah Lactobacillus bulgarius, Lactobacillus casei, Lactobacillus farraginis, Lactobacillus plantarum, Lactobacillus brevis, Lactobacillus uvarum dan masih banyak lagi.( BioToksi $350 \mathrm{ml}$ - Probindo. (n.d.))

Berdasarkan hasil yang ditunjukkan pada

Kesimpulan yang didapatkan dari penelitian ini adalah (1) Sinbiotik G12 dan dan Biotoksi menunjukkan kemampuan sebagai antibiofilm terhadap Staphylococcus aureus, (2) Kadar MBIC yang ditunjukkan oleh Sinbiotik G12 dan dan Biotoksi terhadap Staphylococcus aureus masing-masing sebesar $70.17 \%$ dan $68.74 \%$. (3) Hasil pada yakult diperoleh $11.01 \%$ sehingga tidak menunjukan kemampuan sebagai antibiofilm terhadap Staphylococcus aureus.

\section{UCAPAN TERIMA KASIH}

Kami mengucapkan terimakasih yang sebesar besarnya kepada UPPM Fakultas Kedokteran Universitas Islam Indonesia karena telah memfasilitasi terlaksananya penelitaian ini.

\section{DAFTAR PUSTAKA}

Antarini, A. A. N. (2011). Sinbiotik antara prebiotik dan probiotik. Jurnal IImu Gizi, 2(2), 148-155.

BioToksi $350 \mathrm{ml}$ - Probindo. (n.d.). Retrieved June 25, 2021, from https://probindobiosyafa.com/prod uct/biotoksi-350ml/ 
Afivudien Muhammad \& Irena Agustiningtyas/ Vol 4 (1) 2021, 41-45

Chaerunisa, R. (2015) 'Pengujian aktivitas biofilm Staphylococcus aureus oleh seduhan daun teh putih ( Camellia sinensis ( $\mathrm{L}$.) Kuntze ) pengujian aktivitas penghancuran biofilm Staphylococcus aureus oleh seduhan daun teh putih ( Camellia sinensis ( L .) Kuntze )', Skripsi.

Pratiwi, S. U. T. et al. (2015) 'Antimicrobial effects of indonesian medicinal plants extracts on planktonic and biofilm growth of pseudomonas Aeruginosa and Staphylococcus Aureus', International Journal of Pharmacy and Pharmaceutical Sciences, 7(4), pp. 183-191. doi: 10.4172/2376-0354.1000119.

FAO-OMS. (2002). Guidelines for the Evaluation of Probiotics in Food. Report of a Joint FAO/OMS. Working Group on Drafting Guidelines for the Evaluation of Probiotics in Food.

Fuller, R. (1992). History and development of probiotics. Probiotics, 1-8. https://doi.org/10.1007/978-94011-2364-8_1

Winarti, S., Sarofa, U., \& Rodiyah, K. F. (2018). Karakteristik Jelly Drink Sinbiotik dari Susu Kedelai dan Ekstrak Buah Naga Merah (Hylocereus polyrhizus). Agrointek, $12(1), 61$. https://doi.org/10.21107/agrointek. v12i1.3806 